\title{
Fibre, physical and mechanical properties of Ghanaian hardwoods
}

\author{
Emmanuel Tete Okoh \\ Department of Furniture Design and Production, Accra Polytechnic, P O Box GP 561, Accra, Ghana \\ Email address: \\ etokoh@apoly.edu.gh
}

To cite this article:

Emmanuel Tete Okoh. Fibre, Physical and Mechanical Properties of Ghanaian Hardwoods. Journal of Energy and Natural Resources. Vol. 3, No. 3, 2014, pp. 25-30. doi: 10.11648/j.jenr.20140303.11

\begin{abstract}
Wood fibre properties (fiber length, fiber width, cell wall thickness and lumen diameter), physical (oven-dry density) and mechanical properties (modulus of rupture, modulus of elasticity, compression parallel to the grain) of four tropical hardwood species (Terminalia superba (Ofram) and Terminalia ivorensis (Emere), as currently threatened timber species and Quassia undulata ( Hotrohotro) and Recinodendron heudelotii(Wama) as lesser used timber species were investigated to measure and compare their timber properties as potential substitutes. Tree normal trees of each tree species were selected and log samples were cut at the middle portion of stem height to determine the properties. The study revealed that, the densities, compression parallel to grain, modulus of rapture and modulus of elasticity of Ofram and Hortrohotro were not significant, but that of Emere and Wama were significant. The modulus of elasticity of Emere was however not significant. Based on these findings Hortrohotro could be substituted for Ofram and Emere with Wama.
\end{abstract}

Keywords: Fiber, Hardwood, Mechanical Properties, Lumen

\section{Introduction}

The cells that make up the anatomical structure of tropical hardwoods are the vessels, fibres, parenchyma and the wood rays. Fibres are the most important element that is responsible for the strength of the wood [1]. According to [2], wood density is an important wood property for both solid wood and fibre products. [3], also reported that factors that determine wood density are cell wall thickness, the cell diameter, the ratio of early wood to latewood and the chemical content of the wood. [4], indicated that density is a general indicator of cell size and is a good predictor of strength, stiffness, ease of drying, machining, hardness and various paper making properties. Many of the density variations within a tree can be ascribed to the anatomical structure of wood, such as characteristics of vessels and fibres [5]. Wood density also serves as an indicator of wood quality due to its strong positive correlation with, for example, mechanical strength properties [6]. According to [7], density is one of the most important properties that influences the use of a timber. Also [8], stressed the fact that wood density affects the technical performance of wood and in particular the strength and processing behavior of sawn wood and veneer, and the yields of wood fibre in pulp production. [9] reported that wood density is a measure of the cell wall material per unit volume and as such gives a very good indication of the strength properties and expected pulp yields of timber [10]. According to [11], basic density is closely related to end-use quality parameters such as pulp yield and structural timber strength. [12] stated that the density of wood is recognized as the key factor influencing wood strength. [13] agreed that much of the variation in wood strength, both between and within species, can be attributed to differences in wood density.

Wood density is, therefore, the single most important single factor determining pulp yield and quality and is also reasonably closely related to various wood properties, for example timber strength, and properties of sawing, machining, glueing, shrinkage, seasoning, peeling and, preservation [14]. Density has been shown to be positively correlated with the strength and stiffness of small clear samples of wood [15], and consequently high density timber is generally associated with superior mechanical performance. In structural size samples, however, the presence of other strength reducing factors mean that density alone is not always a good predictor of mechanical properties. Although for sawn timber, variations in tracheid length per se are not generally considered to have a significant impact, short tracheids are associated with high microfibril angles which do reduce timber strength, stiffness 
and dimensional stability. Wood density is a measure of the amount of cell wall material present but gives no indication of the anatomy of the cell wall nor of its properties. For example, compression wood is denser than normal wood but is weaker. [16] concluded that while density was of significance in affecting wood strength in Sitka spruce, it was not as important as other factors, such as grain angle and the presence of juvenile wood, which lower performance. This has been supported by [17] who found that variations in wood density only explained part of the variations in mechanical properties observed in trees of differing growth rates, and that this was particularly evident for Abies and Picea species. A relatively small change in wood density can be accompanied by a considerably larger change in mechanical properties, with the result that estimates of structural performance based solely on evaluation of wood density may not be reliable [18]. [19] reported that density was highly significant, although not the most important, influence on Sitka spruce batten stiffness. Hence, density clearly has an important influence on timber strength and stiffness, but the impact on utilization depends on the integration of other factors such as knots, grain angle and juvenile wood.

The Ghanaian forest is a continuum of the tropical forest with fast growing timber species which are used in a wide variety of applications. The current well known primary timber species in Ghana have been exploited selectively by millers, but mostly without permission by illegal chain saw operators, resulting in their reduction both in number and quantum of each of them and the urgent need for finding alternatives for use by both local and the export industry as well as their contribution to the local economy.

Furthermore, there is also ample evidence that timber production in Ghana is not proportional to its potential. Because, its under-utilization is partly as a result of the lack of general information about the wood properties and the great number of timber species. Consequently, Terminalia superba (Ofram) and Terminalia ivorensis (Emere), as currently threatened timber species and Quassis undulata (Hotrohotro) and Recinodendron heudelotii (Wama) as lesser used timber species were selected for the study to investigate and compare the physical, anatomical and mechanical properties as these properties form the basis for specifying timber for any structural application.

The objective of this work is to measure and compare the variation of physical, anatomical and mechanical properties of Emere and Ofram which are currently threatened timber species to that of Wama and Hortrohotro which are lesser used species as potential substitutes for utilization.

\section{Materials and Methods}

The study area is Kajease Forest reserve at Afosu $\left(06^{\circ} 22^{\prime} \mathrm{N}, 00^{\circ} 57^{\prime} \mathrm{W}\right)$ and an elevation of $217 \mathrm{~m}$ in the Eastern Region. The vegetation is characterized by the moist semi-deciduous forest. The total land area is $1557 \mathrm{~km}^{2}$ and an altitude ranging from $152-610 \mathrm{~m}$ above sea level. It is characterized by a wet semi-equatorial climate with annual rainfall ranging from $1,500-1800 \mathrm{~mm}$. The forest floor is closed with tree species of the Celtic-Triplochiton association, dominated by Celtic mildbraebii (esa), Triplochiton scleroxylon (wawa), Ceiba pentandra (silk cotton), Ricinodendron heudelotii(Wama), Hannoa klaineana (Hotrohotro)), Melicia exelsa (Odum), Khaya ivorensis (African Mahogany), Terminalia ivorensis (emere), Terminalia superba (Ofram) and Entandrophragma cylindricum (Sapele). The timbers extracted for the research were taken from the yield allocated to the contractor by the Forest Services Division (FSD) of the Forestry Commission. Each timber felled had a merchantable diameter of least $60 \mathrm{~cm}$. Inventory records from FSD was used to determine the age of the trees. From each of the species, three normal tress were selected. Logs were cut at the middle portion of stem of tree height. All testing samples were taken from mature wood for the determination of the different wood properties.

Sample Preparation: Defect free boards of, Ricinodendron heudelotii (Wama), Hannoa klaineana (Hotrohotro)), Terminalia ivorensis., (Emeri) and Terminalia superba (Ofram) were cut from the middle portion of trees into $15 \mathrm{~mm}$ thick boards with multiple rip saws. All boards were prepared with the same equipment. Maceration: Fibres were separated by maceration of match stick sized wood pieces originating from 5 arbitrary chosen samples per species in Jeffrey's solution at $40^{\circ} \mathrm{C}$ for $4 \mathrm{~h}$. The resulting cell suspension was washed thoroughly with distilled water. Fibres were spread from this suspension onto a glass slide and left to dry for $12 \mathrm{~h}$.

A Leica EZ 4D light microscope was used to determine the diameter and ratio of vessels, as well as the fibre length and amount of parenchyma cells. Fifteen images were acquired per section for cell analysis. To determine the number of vessels per $\mathrm{mm}^{2}$ and the vessel diameter, images were acquired with a magnification of $20 \mathrm{x}$ and all visible vessels counted and their diameter recorded. Fifteen images of the cell suspension were acquired for each species at a magnification of $35 \mathrm{x}$, and the length of fibres, and parenchyma cells, as well as their amount per $\mathrm{mm}^{2}$ were determined.

A Leica EZ 4D light microscope was used to determine the fibre diameter and cell wall thickness. The fiber diameter and cell wall thickness were determined from fifteen images acquired with a magnification of 4x. Fiber diameter and cell wall thickness were measured on all visible cells in the image.

Density: Twenty samples were dried for $24 \mathrm{~h}$ at $105^{\circ} \mathrm{C}$ before being tested for density. The density of wood was determined on a dry-mass basis. A digital caliper was used to measure the dimensions of the samples of oven-dried wood at a moisture content of $12 \%$ in order to determine their volumes. The samples were then weighed using an electronic balance. The calculated volume was divided by the mass to obtain the density $(\rho)$, using the formula below:

$$
\rho=m / v
$$


where $\rho$ is density $\left(\mathrm{g} \cdot \mathrm{cm}^{3}\right), \mathrm{m}$ is mass $(\mathrm{g})$, and $\mathrm{v}$ is volume $\left(\mathrm{cm}^{3}\right)$.

Mechanical properties: The Flexure Testing Machine was used to determine the Modulus of rupture and the Modulus of elasticity. The sample dimensions for determination of mechanical properties were $450 \times 50 \times 15 \mathrm{~mm}$ for static bending strength tests, such as modulus of rupture (MOR) and modulus of elasticity (MOE) and the compression parallel to grain[CPG(бcpl)].

The prepared samples $(\mathrm{N}=5$ for each species) were then conditioned in a room at a temperature of $20^{\circ} \mathrm{C}$ and $65 \pm 5 \%$ relative humidity until the specimens reached an equilibrium moisture content of $12 \%$. The load was applied in the tangential direction. The mechanical strength properties were calculated using the following equation;

$$
\begin{aligned}
& \mathrm{MOR}=3 \mathrm{PL} / 2 \mathrm{db}^{2} \\
& \mathrm{MOE}=\mathrm{P}^{\prime} \mathrm{L}^{3} / 4 \Delta^{\prime} \mathrm{bd}^{3}
\end{aligned}
$$

where $\mathrm{P}^{\prime}=$ load at the limit of proportionality $(\mathrm{kN}) ; \mathrm{P}=$ maximum load $(\mathrm{KN}), \mathrm{L}=$ span of the test specimen $(\mathrm{mm})$, $\mathrm{b}=$ breadth of the test specimen $(\mathrm{mm}), \mathrm{d}=$ depth of the test specimen $(\mathrm{mm})$ and $\Delta^{\prime}=$ deflection at the limit of proportionality $(\mathrm{mm})$.

$$
\sigma \mathrm{cpl}=\operatorname{Pmax} / \mathrm{A}
$$

Where $\sigma c p l=\operatorname{MCS}(\mathrm{MPa})$,

Pmax $=$ maximum crushing load at break point $(\mathrm{KN})$ and

$\mathrm{A}=$ area of cross section of the specimen on which force was applied $\left(\mathrm{mm}^{2}\right)$.

Statistical analysis to determine the effect of hardwood species on anatomical (fiber length, fiber width, cell wall thickness and lumen diameter), physical (oven-dry density) and mechanical properties (modulus of rupture and modulus of elasticity), was conducted using the analysis of variance (ANOVA) techniques. Duncan's multiple range test (DMRT) was used to test the statistical significance at the $\alpha=0.05$ level. The Pearson correlation was used to analyze the relationship among the wood's various properties.

\section{Results and Discussions}

Fibre cell dimensions: The analysis of variance (ANOVA) shows that there is significant difference between the wood species and their fibre cell dimensions. Wama has by far the highest values for fibre length, cell wall thickness and rankle ratio or wood fraction, but the lowest fibre diameter. Although Hotrohotro has the highest fibre diameter it recorded the lowest cell wall thickness and rankle ratio or wood fraction. Emere and Ofram however recorded intermediate fibre cell values. All these anatomical properties are displayed in Table 1.

Table 1. Fibre cell mean values ( $m \pm S E$ ) of the wood species $(n=5)$

\begin{tabular}{lllll}
\hline Species & Fibre diameter/ $\mathbf{\mu m}$ & Fibre length/mm & Cell wall thickness/ $\mathbf{\mu m}$ & Rankle ratio \\
\hline \multirow{2}{*}{ Hotrohotro } & $29.984 \pm 5.119$ & $1.588 \pm 0.221$ & $6.695 \pm 1.099$ & $0.207 \pm 0.035$ \\
& $\mathrm{~B}$ & $\mathrm{~A}$ & $\mathrm{~A}$ & $\mathrm{~A}$ \\
Ofram & $28.481 \pm 6.937$ & $1.314 \pm 0.239$ & $7.258 \pm 1.389$ & $0.283 \pm 0.142$ \\
& $\mathrm{~B}$ & $\mathrm{~A}$ & $\mathrm{AB}$ & $\mathrm{A}$ \\
Emere & $29.241 \pm 5.931$ & $1.314 \pm 0.244$ & $8.359 \pm 2.625$ & $0.303 \pm 0.146$ \\
& $\mathrm{~B}$ & $\mathrm{~A}$ & $\mathrm{AB}$ & $\mathrm{A}$ \\
Wama & $20.256 \pm 2.804$ & $1.727 \pm 0.528$ & $8.744 \pm 946$ & $0.432 \pm 0.111$ \\
\hline
\end{tabular}

Note: columns with same letters are not significantly different at $\mathrm{p}=0.05$ columns with different letters are significantly different at $\mathrm{p}=0.05$

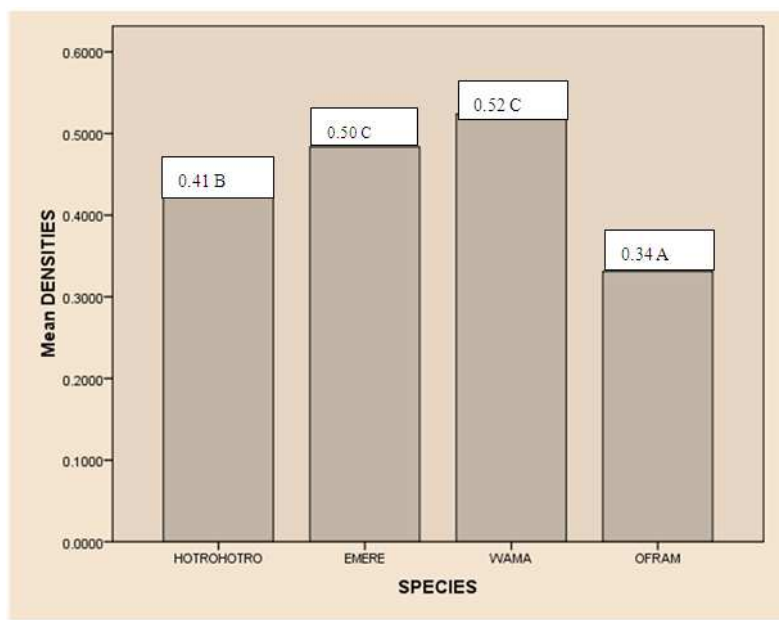

Fig. 1. Oven dry density values of the four hardwood species $\left(\mathrm{g} / \mathrm{cm}^{3}\right)$
Oven dry density: The oven dry density values for the four the tropical hardwood species are displayed in fig. 1 below. It is evident from fig. 1 that Wama had the highest density of $0.524 \mathrm{~g} / \mathrm{cm}^{3}$, whilst Ofram had the lowest of $0.331 \mathrm{~g} / \mathrm{cm}^{3}$. The analysis of variance (ANOVA) shows that there is significant difference between the types of species and oven dry density value. [20] puts the wood density value of Ofram between $0.37-0.73 \mathrm{~g} / \mathrm{cm}^{3}$ which is a little higher than the one determined by this work.

Also [21] Dudek, Förster, and Klissenbauer (1981) quote the wood density value of Hotrohotro between $0.29-0.45 \mathrm{~g} / \mathrm{cm}^{3}$, and this is consistent with the wood density value of $0.41 \mathrm{~g} / \mathrm{cm}^{3}$ determined by this study. Wama had a wood density value of $0.524 \mathrm{~g} / \mathrm{cm}^{3}$ which is little higher than the one determined by [22]( Richter and Dallwitz, 2000). The differences in wood density values for Wama and Ofram may be due to differences in soil and climatic conditions.

Mechanical Properties: The mechanical properties 
[Compression parallel to grain (CPG), Modulus of Elasticity (MOE) and Modulus of Rapture (MOR)] of the wood species are measured to serve as the basis for timber specification and utilization. The results are shown in the figures below.

Fig. 2 shows the compression parallel to grain of the four hardwood species (e.g Ofram, Emere, Wama and Hotrohotro) used for the study. Emere had the highest of compression strength of 25.37 MPa with Ofram. The analysis of variance (ANOVA) shows that there is no significant difference between the type of species and the compression parallel to grain.

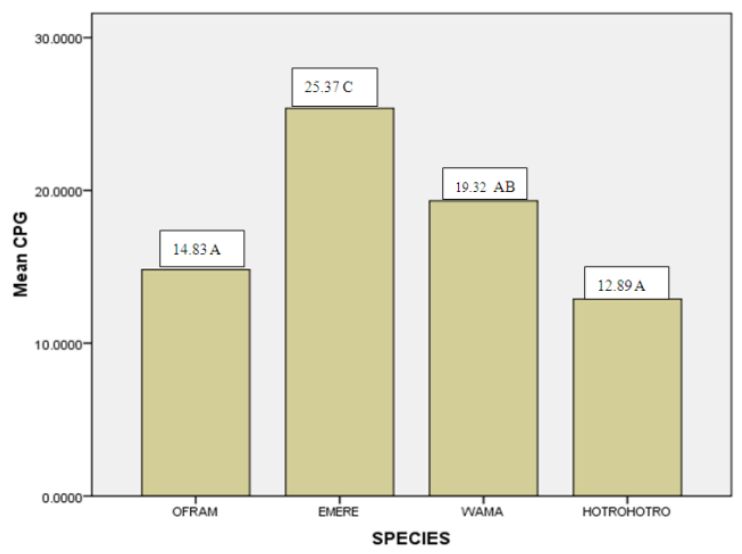

Fig. 2. shows the compression parallel to grain of the four hardwood species.

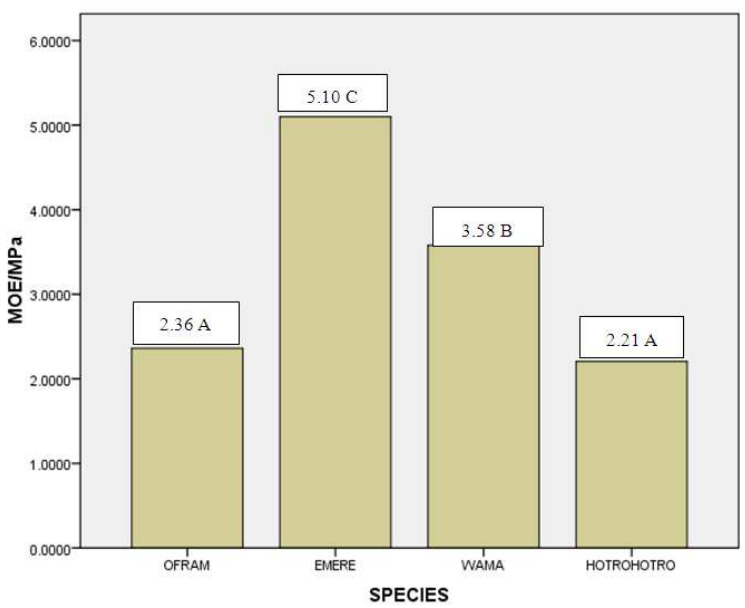

Fig. 3. Modulus of elasticity(MOE) of the four hardwood species
Modulus of Elasticity: The modulus of elasticity (MOE) values for the four hardwood species such as Ofram, Emere, Wama and Hotrohotro are depicted in fig. 3 above. The MOE values for the species are 2.361, 5.099, 3.579 and 2.206 MPa respectively. The analysis of variance (ANOVA) shows that there is significant difference between the types of species and the modulus of elasticity values. The highest value of 5.099 was recorded in Emere with Hotrohotro having the least value of $2.206 \mathrm{MPa}$

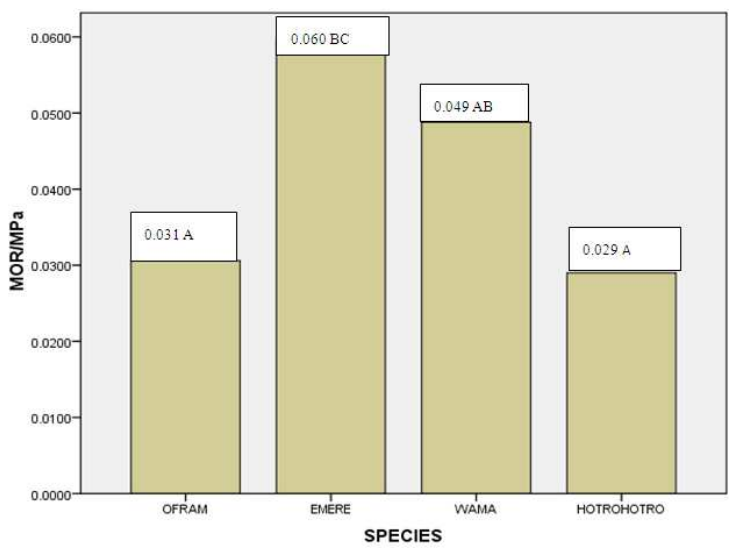

Fig. 4. Modulus of Rapture values of the four hardwood species( MPa)

Modulus of rapture: The modulus of rapture (MOR) values for the four hardwood species are shown in fig. 4. Emere recorded the highest rapture value of $0.060 \mathrm{MPa}$, whilst Hotrohotro had the least rapture value of $0.029 \mathrm{MPa}$. Ofram and Wama however recorded intermediate values. The analysis of variance (ANOVA) shows that there is significant difference between the type of species and the modulus of rapture. The relationship between oven dry density and mechanical properties are shown in Table 1. Results show that there are positive correlation between wood density and CPG $\left(\mathrm{R}^{2}=0.644\right)$, (ANOVA) shows that there is significant difference between the type of species and the modulus of rapture.

The relationship between oven dry density and mechanical properties are shown in Table 3. Results show that there are positive correlation between wood density and $\mathrm{CPG}\left(\mathrm{R}^{2}=0.644\right)$,

$\operatorname{MOR}\left(R^{2}=0.680\right)$ and Modulus of Elasticity $\left(R^{2}=0.646\right)$ at four different species level.

Table 2. The relationship between different wood properties $(p=0.01)$

\begin{tabular}{|c|c|c|c|c|c|c|c|}
\hline & Do & CPG & MOR & MOE & FD & FL & CWT \\
\hline Do & 1 & & & & & & \\
\hline CPG & $0.644^{* *}$ & 1 & & & & & \\
\hline MOR & $0.680^{* *}$ & $0.878^{* *}$ & 1 & & & & \\
\hline MOE & $0.646^{* *}$ & $0.910^{* *}$ & $0.764^{* *}$ & 1 & & & \\
\hline FD & -0.281 & -0.022 & -0.110 & 0.101 & 1 & & \\
\hline FL & 0.251 & -0.092 & -0.133 & 0.017 & -0.074 & 1 & \\
\hline CWT & 0.375 & 0.084 & 0.168 & 0.049 & -0.260 & -0.089 & 1 \\
\hline
\end{tabular}

Do: Oven dry density, CPG: Compression parallel to Grain, MOR: Modulus of Rapture, MOE: Modulus of Elasticity, FD: Fibre Diameter, FL: Fibre Length, FCWT: Fibre Cell Wall thickness 
The relationship between wood density and mechanical strength properties within a species have been investigated tremendously by researchers. The relationship between wood density and mechanical properties within a species has been studied by many researchers. [23] observed that a significant linear relationship exists between wood density and mechanical properties of timber. According to [24] the modulus of rupture and the maximum crushing strength in compression parallel to the grain are most closely and almost linearly related to wood density, whereas modulus of elasticity is poorly and least linearly related to wood density [25]. The density of timber is a function of both cell wall thickness and lumen diameter and there exists correlation between strength and density of timber. The results of this study show a significant linear relationship between wood density and mechanical strength properties of timber.

Although there are positive relationship between wood density and mechanical strength properties, their biometric features (fibre diameter and fibre length) are weak and negatively correlated. Interestingly, the relationship between wood density and mechanical properties with fibre cell wall thickness is positive though weak at four species level. There are also positive relationship between MOR and CPG $\left(\mathrm{R}^{2}=0.878\right)$, MOE and CPG $\left(\mathrm{R}^{2}=0.910\right)$ and MOE and $\operatorname{MOR}\left(\mathrm{R}^{2}=0.764\right)$.

\section{Conclusion}

The study revealed that, the densities, compression parallel to grain, modulus of rapture and modulus of elasticity of Ofram and Hortrohotro were not significant, but that of Emere and Wama were significant. The modulus of elasticity of Emere was however not significant. There were however positive relationships between wood density and MOE, CPG and MOR, but not fibre cell dimensions. Based on these findings Hortrohotro could be substituted for Ofram and Emere with Wama.

\section{References}

[1] A. J. Pan,shin, and C. de Zeeuw, Textbook of wood technology(4th ed.).1980. New York: McGraw-Hill

[2] De Guth, E.B., (1980), Relationship between wood density and tree diameter in Pinus elliottii of Missiones Argentina. IUFRO Conf. Div. 5 Oxford, England. 1p (Summary).

[3] ID Cave and JCF Walker, Stiffness of wood in fast grown plantation softwoods: the influence of microfibril angle. Forest Prod. J. 44(5), 43-48, 1994.

[4] R.M. Roque, M.T. Filho, Relationships between anatomical features and intra-ring wood density profiles in Gmelina arborea applying x-ray densitometry. Cerne 13:384-392, 2007.

[5] G. Nepveu, Croissance et qualite' du bois de framire'. Evolution de la largeur de cerne et des composantes densitome'triques en fonction de l'age. Bois et Fore`ts des Tropiques 165: 39-58. 1976.
[6] J.D. Brazier and R.S. Howell, The use of a breast height core for estimating selected whole tree properties of Sitka spruce. Forestry. 52(2), 177-185, 1979..

[7] J.D. Brazier and R.S. Howell, The use of a breast height core for estimating selected whole tree properties of Sitka spruce. Forestry. 52(2), 177-185, 1979Cown, D.J, (1992) Core wood (Juvenile Wood) in Pinus radiata- should we be concerned? New Zealand J. Forestry Sci. 22(1), 87-95.

[8] E.W.J. Philips, The inclination of the fibrils in the cell wall and its relation to the compression strength of timber. Empire Forestry J. 20, 74-78, 1941.

[9] E.W.J. Philips, The inclination of the fibrils in the cell wall and its relation to the compression strength of timber. Empire Forestry J. 20, 74-78, 1941.

[10] C, Harvald and P.O. Olesen, The variation of the basic density within the juvenile wood of Sitka spruce (Piceasitchensis). Scand. J. Forest Res. 2, 525-537, 1987.

[11] Cown, D.J, (1992) Core wood (Juvenile Wood) in Pinusradiata- should we be concerned? New Zealand J. Forestry Sci. 22(1), 87-95.

[12] Schniewind, A.P., (1989). Concise encyclopedia of wood and wood-based materials. Pergamon Press. pp: 248.

[13] G. Nepveu, Croissance et qualite' du bois de framire'. Evolution de la largeur de cerne et des composantes densitome'triques en fonction de l'age. Bois et Fore'ts des Tropiques 165: 39-58, 1976.

[14] A. J. Pan,shin, and C. de Zeeuw , C Desch, H.E. and Dinwoodie, J.M., (1996), Timber Structure, Properties, Conversion and Use. MacMillan Press, London.

[15] J.D. Brazier and R.S. Howell, The use of a breast height core for estimating selected whole tree properties of Sitka spruce. Forestry. 52(2), 177-185, 1979

[16] Zhang, S.Y., (1997) Wood quality: its definition, impact and implications for value-added timber management and end uses. In Timber Management Toward Wood Quality and End-Product Value.

[17] S.Y. Zhang, R. Gosselin and G. Chauret (eds). Proceedings of the CTIA/IUFRO International Wood Quality Workshop, Quebec City. Part I, pp. 17-39

[18] K.W. Maun (1992), Sitka spruce for construction timber: the relationship between wood growth characteristics and machine grade yields of Sitka spruce. Forestry Commission Research Information Note No. 212. Forestry Commission, Edinburgh

[19] Phongphaew, P., 2003. The commercial woods of Africa. Linden Publishing, Fresno, California, United States. 206 pp.

[20] S. Dudek,, B. Förster, and, K. Klissenbauer, 1981. Lesser known Liberian timber species. Description of physical and mechanical properties, natural durability, treatability, workability and suggested uses. GTZ, Eschborn, Germany. $168 \mathrm{pp}$

[21] H.G. Richter, and M.J. Dallwitz, Commercial timbers: descriptions, illustrations, identification, and information retrieval. 2000. [Internet]. Version 18th October 2002. http://delta-intkey.com/wood/index.htm. Accessed May 2005. 
[22] S.Y. Zhang, R. Gosselin and G. Chauret (eds). Proceedings of the CTIA/IUFRO International Wood Quality Workshop, Quebec City. Part I, pp. 17-39.

[23] S.Y. Zhang, Effect of growth rate on wood specific gravity and selected mechanical properties from distinct wood categories. Wood Sci. Technol. 29, 451-465, 1995.
[24] J.M. Dinwoodie, Timber Structure, Properties, Conversion and Use. 1996. MacMillan Press, London. 